\title{
Dynamic Characteristics and Time-History Analysis of Hydraulic Climbing Formwork for Seismic Motions
}

\author{
Gang Yao, ${ }^{1,2}$ Haoting Guo, ${ }^{1,2}$ Yang Yang $\mathbb{D}^{1,2}$ Chengming Xiang, ${ }^{1,2}$ and Soltys Robert ${ }^{3}$ \\ ${ }^{1}$ Key Laboratory of New Technology for Construction of Cities, Mountain Area, Ministry of Education, Chongqing, China \\ ${ }^{2}$ School of Civil Engineering, Chongqing University, Chongqing, China \\ ${ }^{3}$ Technical University Kosice, Kosice, Slovakia
}

Correspondence should be addressed to Yang Yang; yy20052710@163.com

Received 12 January 2020; Revised 21 January 2021; Accepted 25 February 2021; Published 12 March 2021

Academic Editor: Li Li

Copyright (c) 2021 Gang Yao et al. This is an open access article distributed under the Creative Commons Attribution License, which permits unrestricted use, distribution, and reproduction in any medium, provided the original work is properly cited.

With the widespread use and increasing cycle life of climbing formwork to construct high-rise buildings in earthquake-prone areas, the risk of earthquakes during the construction period increases. Hence, it is necessary to analyze the seismic response of climbing formwork. According to actual climbing formwork in the super high-rise office building of Wanda Plaza in Kunming, China, the finite element model of the climbing formwork is established on the Ansys platform. The correctness of the model is verified by comparing the natural frequencies of the actual climbing formwork and the finite element model. The time-history analysis of the climbing formwork subjected to earthquakes of varying strong magnitudes is carried out. The maximum displacement position and maximum von Mises stress position of the climbing formwork under different working conditions are determined, and the seismic response of the climbing formwork is analyzed. It has been found that when the formwork is under construction, the maximum displacement position of the climbing formwork is at the center of the long beam of the upper platform, and the maximum von Mises stress position is the joint of the outer pole of the main platform and tripod. Under the climbing condition, the maximum displacement position of the climbing formwork is at the top of the outer pole of the upper platform, and the maximum von Mises stress position is the joint of the beam of the tripod and guide rail. The climbing formwork is partially damaged under the simulated earthquake. However, the displacement is large, and some components have reached the yield state. It is recommended to strengthen the connection between the upper platform and the guide rail and enhance the strength and rigidity of the outer pole and tripod. Climbing formwork is more sensitive to horizontal earthquakes and has minimal sensitivity to vertical earthquakes. The structure attached to the climbing formwork will reduce its sensitivity to earthquakes. The research results are of practical significance for seismic design and improvement of climbing formwork.

\section{Introduction}

With the progress of technology, climbing formworks are more widely used in the construction of high-rise buildings [1]. Some scholars have done research on climbing formwork from different angles. Much of the research on climbing formwork focuses on the structural design and engineering applications of the climbing formwork. Jianet et al. [2] studied the structural design of a 30-degree sloped climbing formwork. Zou et al. [3] studied the design of alternating climbing formwork for mass concrete cofferdams. Li et al. [4] designed the structure of the climbing formwork for the inclined tower structure. Xia et al. [5] calculated and analyzed the hydraulic climbing form of Shanghai International Financial Center and proposed a structural measure to improve the lateral stiffness of the climbing formwork. A small number of studies have focused on optimizing the use and planning the layout of the climbing formwork. Emadaldin et al. [6] proposed a symbolic regression method called linear biogeography-based programming and applied it for extracting a formula that obtains a good climbing rate of slip formwork systems. Artificial neural network and linear genetic programming were utilized to evaluate the performance of the proposed method. Ju et al. [7] proposed a method for automated layout planning of climbing formwork based on a genetic algorithm. 
At present, the average height of buildings in the world is increasing, the construction period is getting longer, and the safety of building structures during construction is receiving more and more attention. According to the statistics of the China Earthquake Administration, in 2018, 549 earthquakes with a magnitude 3.0 or above in China were recorded [8]. In earthquake-prone areas, buildings are more likely to come across earthquakes during the construction phase. Due to the importance of the earthquake resistance of the structure, the seismic performance of the structure and the protection measures against earthquakes have been considered and studied. For most earthquakes in China, buildings in earthquake-prone areas have not been damaged due to good seismic performance and protective measures [9-11]. Similarly, the safety of temporary construction structures such as climbing formwork has also received more and more attention [12]. Most of the research on the safety of climbing formwork is related to the safety of construction and wind resistance. Liu et al. [13] studied the safety control of hydraulic climbing formwork, analyzed the main risk factors of hydraulic climbing formwork construction, mainly considering the stability of its connection with the structure, and proposed corresponding control measures. $\mathrm{Hu}$ and $\mathrm{Li}$ [14] analyzed the dynamic characteristics of the climbing formwork under wind load and improved the wind-resistant structure of the climbing formwork.

Limited research on the seismic response and seismic safety design has been found for climbing formwork, and manufacturers of climbing formwork cannot make relevant protection measures for climbing formwork. The reason is that there were no sufficient experiences related with the behavior of nontraditional structures under earthquake action. Although a great deal of research has been done on hydraulic climbing formwork, there are few reports on the seismic performance of hydraulic climbing formwork. There is not even a specific seismic design code for climbing formwork in China [15]. Many temporary construction structures such as climbing formwork at the construction site have less resistance to earthquakes. When subjected to earthquakes, they will be damaged or even collapsed, causing huge economic losses and endangering the lives of construction workers on-site [16]. During the Wenchuan earthquake, many climbing formwork were destroyed or even collapsed at the construction site. In Xi'an, the temporary construction structures of more than 100 construction sites were damaged, causing significant economic losses [17]. In 2014, many earthquakes occurred in Ludian, Pu'er, and Jinghong in Yunnan, China. During the construction of the Wanda Plaza in Yunnan, the climbing formwork was damaged to varying degrees in several earthquakes, resulting in delays in construction and economic losses. From 2016 to 2019, there were 34 accidents in China due to temporary construction structures such as climbing formwork, which caused the death of construction workers [18]. The possibility of the climbing formwork being subjected to earthquakes increases with its ubiquity and the longer construction period of tall buildings. Moreover, due to the high-altitude work of the hydraulic climbing formwork system, the load environment of the hydraulic climbing formwork system is complex in the construction process, and the boundary conditions of the climbing formwork system change alternately in the construction and climbing states, which has a great influence on the seismic performance under different working conditions. In summary, it is necessary to study the seismic response of the climbing formwork.

Based on the measured high-magnitude earthquakes, the RIM-SCS80 climbing formwork in the actual engineering (super high-rise office building of Xishan Wanda Plaza in Kunming, China) is used as the analysis object, and the finite element model is established on the Ansys platform. Considering the typical working conditions of construction and climbing, the seismic response of the climbing formwork is studied.

\section{Engineering Background}

This research is based on the super high-rise office building of Xishan Wanda Plaza in Kunming, China. As shown in Figure 1, the core tube is constructed using RIM-SCS80 climbing formwork. The climbing formwork structure mainly includes an upper platform, two medium platforms, a main platform, a tripod, a guide rail, a hydraulic operating platform, and a hanging platform. The detailed uses and sizes of each platform in climbing formwork are shown in Table 1.

Yunnan, China, is located on the side of the Eurasian seismic belt and is a region with frequent earthquakes. In the construction process of super high-rise buildings, it is highly likely to suffer from earthquakes. Therefore, it is necessary to analyze the seismic response of the climbing formwork during actual engineering under strong earthquakes and provide references for seismic design and improvement of climbing formwork.

\section{Finite Element Model}

3.1. Model Establishment. In this study, the simplified finite element model of climbing formwork and core tube are established on the Ansys platform, and the dynamic characteristics and seismic response of the climbing formwork are analyzed.

Since the climbing formwork is attached to the outer wall of the core tube, the influence of the dynamic characteristics of the core tube cannot be ignored. In this study, the core tube is simplified, and simultaneously, the complete core tube is simplified to a cuboid mass with infinite stiffness and mass M. It is modeled with Solid45 (Three-Dimensional Structural Entity Unit) hexahedral solid element. A fixed boundary condition is applied below the core tube to constrain the vertical displacement of the core tube. The lateral stiffness of the core tube in both directions is simplified by Combin14 (Spring-Damper Elements) spring element.

Beam188 (Linear Finite Strain Beam Element) element is used to define the climbing formwork frame member. There are eleven different cross-section types for the climbing formwork. The climbing formwork uses Q235 (a three-dimensional linear beam with two nodes) 


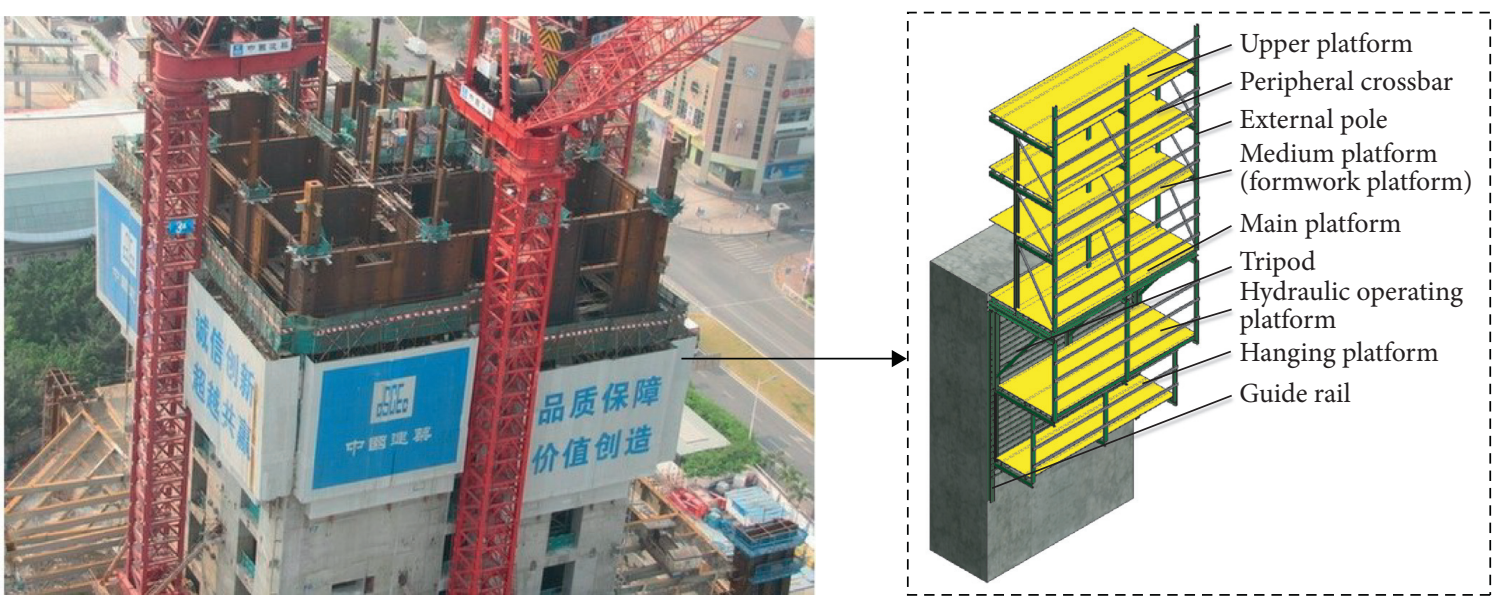

FIgURe 1: Super high-rise office building of Xishan Wanda Plaza and the RIM-SCS80 climbing formwork.

Table 1: Detailed sizes and uses of each platform of climbing formwork.

\begin{tabular}{|c|c|c|c|c|}
\hline Platform & $\begin{array}{c}\text { Width } \\
(\mathrm{m})\end{array}$ & $\begin{array}{l}\text { Height } \\
\text { (m) }\end{array}$ & $\begin{array}{c}\text { Length } \\
\text { (m) }\end{array}$ & Uses \\
\hline Upper platform & 2.5 & 1.8 & 6 & Binding steel bars and pouring concrete \\
\hline Medium platform 1 & 2.5 & 2.0 & 6 & Binding steel bars and formwork construction \\
\hline Medium platform 2 & 1.6 & 2.0 & 6 & Binding steel bars and formwork construction \\
\hline Main platform & 2.5 & 3.0 & 6 & $\begin{array}{l}\text { Installing guide rail, fixing climbing frame, binding steel bars, and } \\
\text { formwork construction }\end{array}$ \\
\hline $\begin{array}{l}\text { Hydraulic operating } \\
\text { platform }\end{array}$ & 2.5 & 2.8 & 6 & Installing hydraulic device, lifting formwork \\
\hline Hanging platform & 1.6 & 2.5 & 6 & Trimming concrete wall \\
\hline
\end{tabular}

steel, the yield stress is $235 \mathrm{MPa}$, the density is $7850 \mathrm{~kg} /$ $\mathrm{m}^{3}$, Poisson's ratio is 0.3 , and the elastic modulus is $206 \mathrm{GPa}$. The main unit parameters of each frame member are shown in Table 2.

This study considers two common conditions of climbing formwork, climbing conditions, and construction conditions. The structure of the climbing formwork is different for the two conditions and is reflected in the finite element model [19]. The influence of the dynamic characteristics of the core tube on the climbing formwork is also considered. Therefore, four finite element models are established in this study. COC model is the Ansys model of climbing formwork considering the core tube under the construction condition. For CLC model, the influence of the core tube is considered, and the climbing formwork is under the climbing condition. For CO model, the influence of the core tube is not considered, and the climbing formwork is under construction condition. For CL model, the influence of the core tube is not considered, and the climbing formwork is under climbing condition. The construction process of RIMSCS80 climbing formwork is shown in Figure 2. The COC and $\mathrm{CO}$ models represent the entire construction phase from the initial state to the installation stage of wall attachment device. The CLC and CL models represent the climbing state of frame body [20].

The four finite element models are shown in Figure 3. The $X, Y$, and $Z$ directions in this study are defined in Figure 3 and are consistently observed.
3.2. Boundary Conditions. Under the construction condition, the upper node of the climbing formwork tripod is connected with the concrete structure through the beam hook and embedded part. The lower node of the tripod pole is directly supported on the concrete structure by the wall bracket. Under the climbing condition, the upper node of the guide rail is fastened by the embedded part, and the lower node is directly supported on the concrete structure. The upper node of the tripod is connected with the guide rail by the safety catch, and the lower node is supported on the concrete structure. The boundary conditions of the finite element model are established by the aforementioned actual connection conditions, as shown in Table 3.

3.3. Load. The considered load of the climbing formwork mainly includes the weight of each platform board, weight of the climbing formwork frame, weight of the formwork, and construction load of each platform. The self-weight of the climbing formwork is defined by the gravity acceleration on the Ansys platform. The self-weight of the formwork, self-weight of each platform board, and construction load are applied to each platform beam by assigning their masses. In addition, the level, direction, and position of load applied on the climbing formwork model are defined in accordance with the real load of an actual climbing formwork. 
TABLE 2: Main unit parameters of climbing formwork.

\begin{tabular}{|c|c|c|c|}
\hline Structural member & Material & Geometric parameters $(\mathrm{mm})$ & Element selection \\
\hline Beam of upper platform & Channel steel & $160 \times 63 \times 6$ & Beam 188 \\
\hline Beam of main platform & Channel steel & $160 \times 63 \times 6$ & Beam188 \\
\hline Beam of other platform & Channel steel & $120 \times 53 \times 5$ & Beam188 \\
\hline Platform pole & Channel steel & $80 \times 43 \times 5$ & Beam188 \\
\hline Platform crossbar & Channel steel & $100 \times 48 \times 5$ & Beam188 \\
\hline Platform slant rod & Round tube steel & $\varnothing 66 \times 3$ & Beam 188 \\
\hline Tripod pole & H-beam & H $175 \times 175 \times 7.5 \times 11$ & Beam188 \\
\hline Tripod slant rod & H-beam & H $125 \times 125 \times 6.5 \times 10$ & Beam 188 \\
\hline Tripod crossbar & H-beam & H $200 \times 200 \times 8 \times 12$ & Beam 188 \\
\hline Guide rail & H-beam & H $150 \times 150 \times 7 \times 10$ & Beam 188 \\
\hline Peripheral keel & Square tube steel & $\square 80 \times 80 \times 3$ & Beam188 \\
\hline
\end{tabular}

: channel steel height $\times$ width $\times$ waist thickness; Ø: round tube steel outer diameter $\times$ thickness; H: H-beam height $\times$ width $\times$ web thickness $\times$ flange thickness; $\square$ : square tube steel height $\times$ width $\times$ thickness.

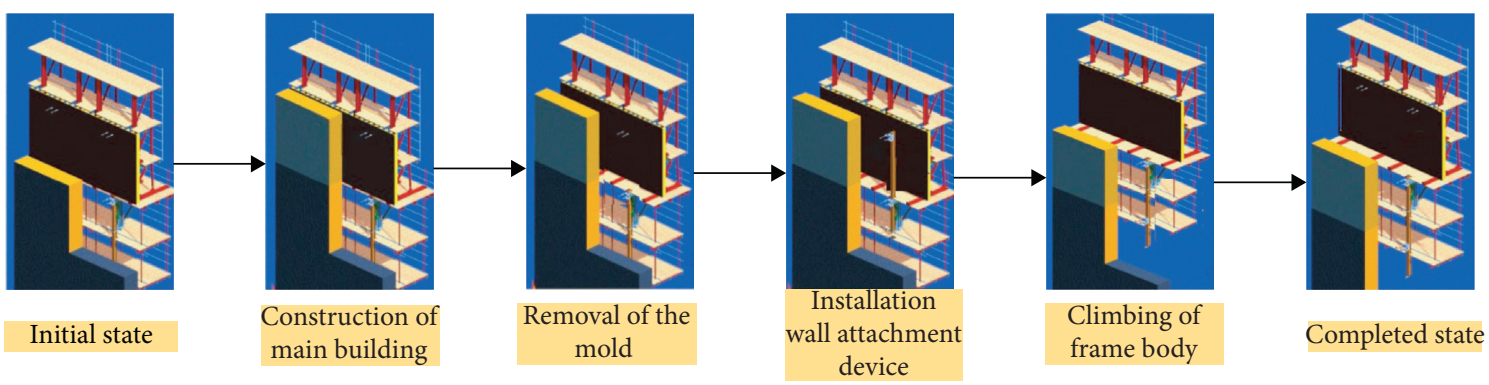

FIGURE 2: The construction process of RIM-SCS80 climbing formwork.

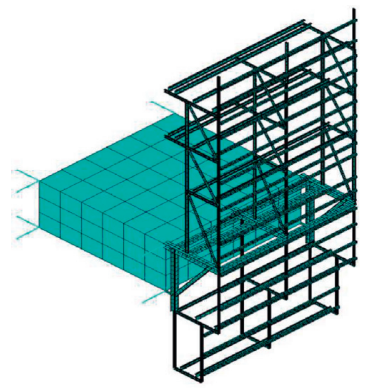

(a)

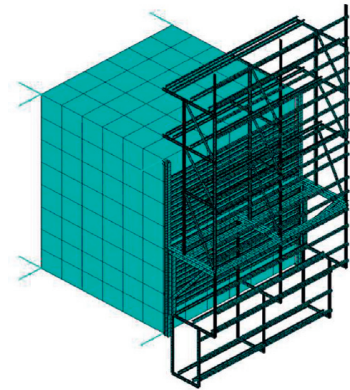

(b)

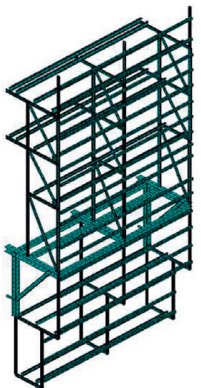

(c)

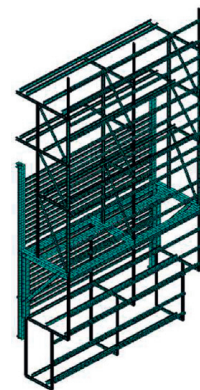

(d)

Figure 3: Finite element models. (a) COC model, (b) CLC model, (c) CO model, and (d) CL model.

TABLE 3: Boundary condition of the finite element model.

\begin{tabular}{lrl}
\hline Working condition & Connection position & Model boundary \\
Construction & The upper node of the tripod and embedded part & Rigid connection \\
& The lower node of the tripod and concrete structure & $\begin{array}{c}\text { Hinge connection } \\
\text { Rigid connection }\end{array}$ \\
The connection between the main frames of climbing formwork & Rigid connection \\
The upper node of the guide rail and embedded part & Hinge connection \\
The lower node of the guide rail and concrete structure & Rigid connection \\
Climbing & The upper node of the tripod and concrete structure & Hinge connection \\
& The lower node of the tripod and guide rail & Rigid connection \\
\hline
\end{tabular}


The standard values of the construction load of the climbing formwork are as follows: the upper platform is $3 \mathrm{kN} / \mathrm{m}^{2}$ (excluding gravity), the main platform is $3 \mathrm{kN} /$ $\mathrm{m}^{2}$ (excluding gravity), the medium platform is $0.75 \mathrm{kN} /$ $\mathrm{m}^{2}$ (Excluding gravity), the hanging platform is $0.75 \mathrm{kN} /$ $\mathrm{m}^{2}$ (excluding gravity), and the hydraulic operating platform is $1.5 \mathrm{kN} / \mathrm{m}^{2}$ (excluding gravity). The load combination satisfies the requirements of "technical specification for construction of the hydraulic climbing formwork" (JGJ195-2010) [21]. Meanwhile, all structure members adopt the ideal elastoplastic model and satisfy the von Mises yield criterion and bilinear kinematic hardening plasticity.

3.4. Working Condition. In this study, two actual seismic records (Cape Mendocino and Turkey Duzce) and one artificial seismic record are selected according to the construction site category and the design earthquake group of the actual engineering (super high-rise office building of Xishan Wanda Plaza in Kunming, China). The three seismic records are numbered CM (Cape Mendocino), TD (Turkey Duzce), and AR (Artificial). Considering four finite element models, twelve sets of working conditions are defined, and the working conditions are shown in Table 4.

\section{Model Verification and Dynamic Characteristics}

The modal analysis of the four finite element models are performed on the Ansys platform to obtain the natural frequency of the climbing formwork and the mode shapes. The dynamic characteristics of the finite element model and the actual climbing formwork are compared and analyzed for verifying the correctness of the finite element model.

4.1. Model Verification. In order to verify the correctness of the simplified finite element model of the core tube, this study compares the natural frequency of the simplified finite element model with the accurate model of the core tube established with PKPM. The accurate model of core tube is based on the super high-rise office building of Xishan Wanda Plaza in China, in accordance with its actual construction plan and design plan. The project adopts a steel reinforced concrete core tube. There are 66 floors above the ground, of which 10, 22, 34, 46, and 58 floors are refuge layers, and the rest are standard layers. The structural roof height is $297.8 \mathrm{~m}$, the first floor height is $10 \mathrm{~mm}$, and the standard floor height is $4.1 \mathrm{~m}$. The 34 refuge layers are $9.5 \mathrm{~m}$ high, and the rest of the refuge layer is $5.9 \mathrm{~m}$ high. There are three floors below the ground, and the basement is $16 \mathrm{~m}$ deep. The thickness of the outer wall is $1300 \mathrm{~mm}-400 \mathrm{~mm}$, and the inner wall is $600 \mathrm{~mm}-200 \mathrm{~mm}$. The seismic fortification intensity is 8 , the design basic seismic acceleration is $0.2 \mathrm{~g}$, the earthquake group is the third group, the site category is class III, and the 50 -year basic wind pressure is $0.3 \mathrm{kN} / \mathrm{m}^{2}$. The PKPM model of core tube and standard layer structure are shown in Figure 4. The first three natural frequencies of the core tube are shown in Table 5. It can be seen from Table 5 that the natural frequencies of the first three modes of the simplified finite element model are basically equal to those of the PKPM accurate model, indicating that the simplified finite element model can effectively simulate the dynamic characteristics of the core tube.

In order to verify the correctness of the finite element model of the climbing formwork, this study compares and analyzes the natural frequency of the simplified finite element model and the actual climbing formwork. In this study, the actual climbing formwork without the core tube fixed at the joint is considered. The natural frequency of the actual climbing formwork is obtained by the environment random vibration stimulating method. Data measurement and acquisition are performed using integrated circuits piezoelectric (ICP) acceleration sensor and the Eastern Coca data acquisition instrument. The sampling frequency is $100.0 \mathrm{~Hz}$, and the sampling time is $10.0 \mathrm{~min}$. According to theoretical analysis and on-site construction conditions, the acceleration sensor should be placed at the position where the structural response is large. Acceleration sensors are, respectively, arranged at the top of the outer pole of upper platform and the center of the long beam of upper platform and the joint of the outer pole of main platform and the tripod. The position of the acceleration sensor on the climbing formwork is shown in Figure 5.

In this study, the stochastic subspace identification (SSI) method is used to simulate the natural frequency of the climbing formwork, and the natural frequencies of the first three modes are obtained. The natural frequencies of the simplified finite element model and actual climbing formwork are demonstrated and compared, in Figure 6 and Table 6. It can be seen that the natural frequency of the finite element model is basically equal to that of the actual climbing formwork. The natural frequency of the climbing formwork is obvious and accurate, and the finite element model is highly accurate. Therefore, the finite element models and analysis results in this study are credible.

4.2. Dynamic Characteristics. The natural frequency and mode shape of the first five modes of the climbing formwork models are shown in Table 7 . The mode shape diagrams of the first three modes of the climbing formwork model are shown in Figure 7.

The following can be seen from the dynamic characteristics of the model.

(1) The first mode shapes and second mode shapes of COC and CLC models are mainly defined by the translation of the core tube, and the third mode shapes are mainly defined by the torsion of the core tube. The first three modes of COC and CLC models are basically equal, which indicates that the first three modes of the climbing formwork model are mainly controlled by the core tube model. For the fourth and aforementioned modes, the modes of the two models are quite different. The main reason is that the two models have different boundary conditions [22-25]. 
TABLE 4: Combination condition.

\begin{tabular}{lccc}
\hline $\begin{array}{l}\text { Working } \\
\text { condition }\end{array}$ & $\begin{array}{c}\text { Climbing formwork } \\
\text { condition }\end{array}$ & $\begin{array}{c}\text { Whether to consider the core tube } \\
\text { Seismic } \\
\text { record }\end{array}$ \\
\hline COC-CM & Construction condition & & CM \\
COC-TD & Construction condition & TD & AR \\
COC-AR & Construction condition & Considering the influence of the dynamic characteristics of the core \\
CLC-CM & Climbing condition & tube & TM \\
CLC-TD & Climbing condition & & AR \\
CLC-AR & Climbing condition & & CM \\
CO-CM & Construction condition & & TD \\
CO-TD & Construction condition & & AR \\
CO-AR & Construction condition & Not considering the influence of the dynamic characteristics of the core & tube \\
CL-CM & Climbing condition & & TD \\
CL-TD & Climbing condition & & AR \\
CL-AR & Climbing condition & &
\end{tabular}

(2) The first three modes of CO and CL models are mainly composed of single vibration mode, which is the bending or torsion of the climbing formwork frame. The fourth mode or more of model $\mathrm{CO}$ is mainly composed of combined vibration modes, including bending and torsion of the frame and the vibration deformation of external pole. The fourth mode or more of model CO is mainly the vibration deformation of the guide rail. Comparing the vibration modes of $\mathrm{CO}$ and CL models, it can be found that the stiffness of climbing formwork under the construction condition is greater than the stiffness under the climbing condition. The main reason is that the climbing formwork adheres to the guide rail under the climbing condition, and the stiffness of the guide rail and the connection between the two affect the overall structural stiffness.

(3) By comparing the vibration modes of $\mathrm{COC}$ and $\mathrm{CO}$ models and the vibration modes of CLC and CL models, respectively, it can be concluded that the influence of the core tube on the climbing formwork is mainly concentrated on the first three modes, and the natural frequency of core tube is smaller than that of climbing formwork.

\section{Seismic Response}

5.1. Selection of Seismic Waves. According to the "Code for Seismic Design of Buildings, China" (GB50011-2010), two actual seismic waves (Cape Mendocino and Turkey Duzce) and one artificial seismic wave are selected, based on the classification of the construction site and seismic design of the structure. The two actual seismic waves belong to the near-fault seismic record. In the seismic record, the strong ground motion is slowly attenuated, and there is a longperiod high-energy pulse. The motion characteristics of the near-fault ground motions are mainly characterized by the hanging wall effect, rupture forward directivity effect, and fling-step effect. The hanging wall effect means that the strong ground motion attenuation of the hanging wall is slower than that of the footwall, and the distribution area of the strong ground motion is large and mainly distributed on the hanging wall. Both the fling-step effect and rupture forward directivity effect result in the long-period pulse. The near-fault seismic records selected and the artificial seismic record have widely different characteristics and therefore can help in drawing a general conclusion about the seismic response of the climbing formwork. The seismic fortification intensity of Kunming is 8, equivalent to the design peak acceleration of ground motion of $0.20 \mathrm{~g}$ [26]. Acceleration time history of the selected seismic record is shown in Figure 8.

The response spectrum curves of the selected seismic record are compared with the design response spectrum curve, as shown in Figure 9. It can be found that the response spectrum curves of the selected seismic waves are statistically consistent with the design response spectrum curve. Therefore, the selection of seismic waves is accurate and reasonable.

5.2. Seismic Response of Climbing Formwork under the Construction Condition. By analyzing and comparing the results of time history analysis of the climbing formwork under different working conditions, the seismic response of the climbing formwork is evaluated. The maximum von Mises stress and maximum displacement of the climbing formwork and its position are determined by observing the peak nephogram. The peak nephograms of the climbing formwork under the working condition CO-CM are shown in Figure 10, and the value and the position of the peak response of the climbing formwork under the construction condition are shown in Table 8 .

The following can be seen from Figure 10 and Table 8.

(1) Under the construction condition, the maximum displacement position of the climbing formwork is at the center of the long beam of the upper platform. The deformation of the center of each platform beam is large, so it is recommended to strengthen the constraint.

(2) The maximum displacement of the climbing formwork model COC is much larger than that of $\mathrm{CO}$ model, and the difference of displacement subjected to different earthquakes is also larger. The reason is that the core tube has different large displacements 

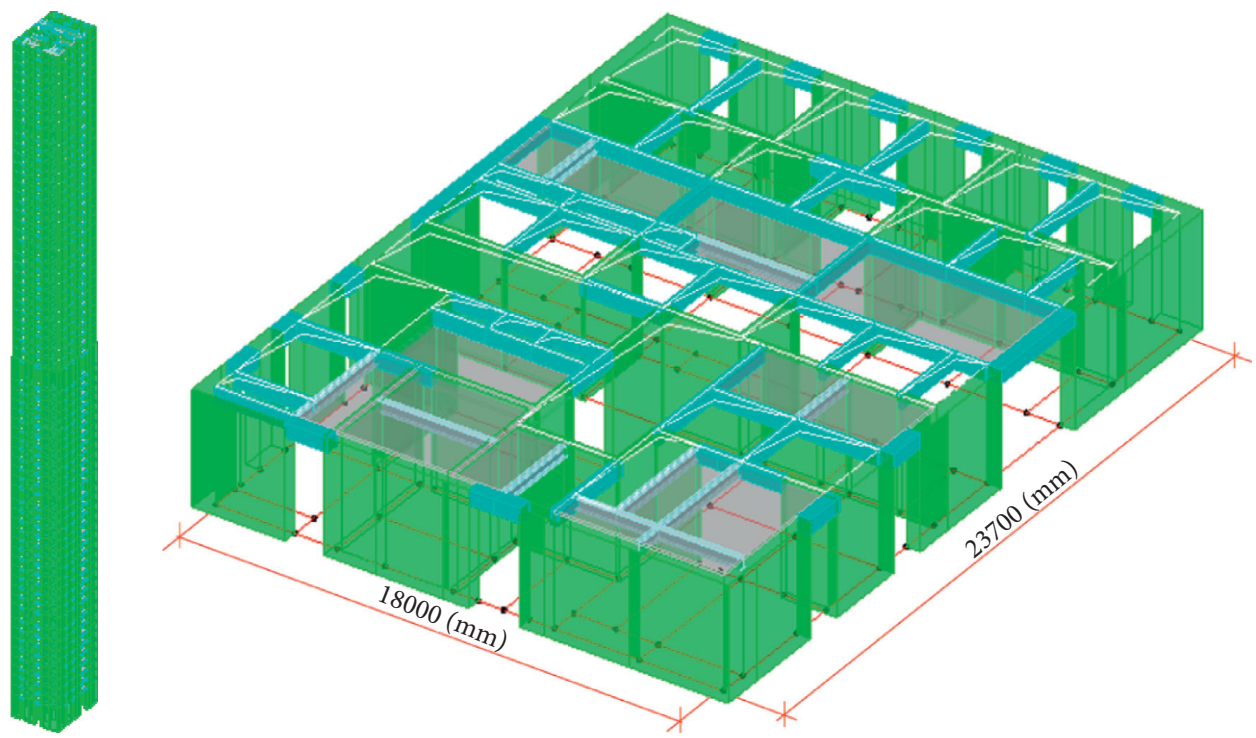

FIgURE 4: PKPM accurate model of core tube and standard layer structure.

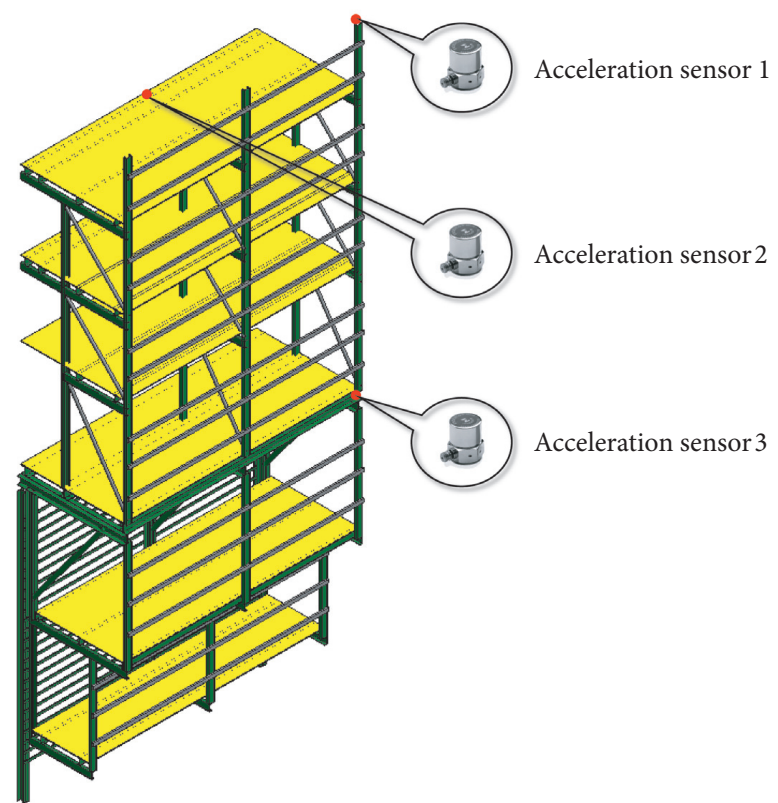

FIgURe 5: Position of the sensor on the climbing formwork.

TABle 5: Comparison between model results and actual measurement results.

\begin{tabular}{lcccc}
\hline \multirow{2}{*}{ Model } & Mode & \multicolumn{3}{c}{ Natural frequency $(\mathrm{Hz})$} \\
& Model calculation & Actual measurement & Deviation (\%) \\
\hline \multirow{3}{*}{ Model CO } & 1 & 1.999 & 2.075 & 3.802 \\
& 2 & 2.890 & 3.054 & 5.567 \\
\hline \multirow{3}{*}{ Model CL } & 3 & 4.827 & 4.854 & 0.559 \\
& 1 & 1.424 & 1.472 & 3.371 \\
& 2 & 1.801 & 1.837 & 1.999 \\
& 3 & 2.004 & 2.056 & 2.259 \\
\hline
\end{tabular}




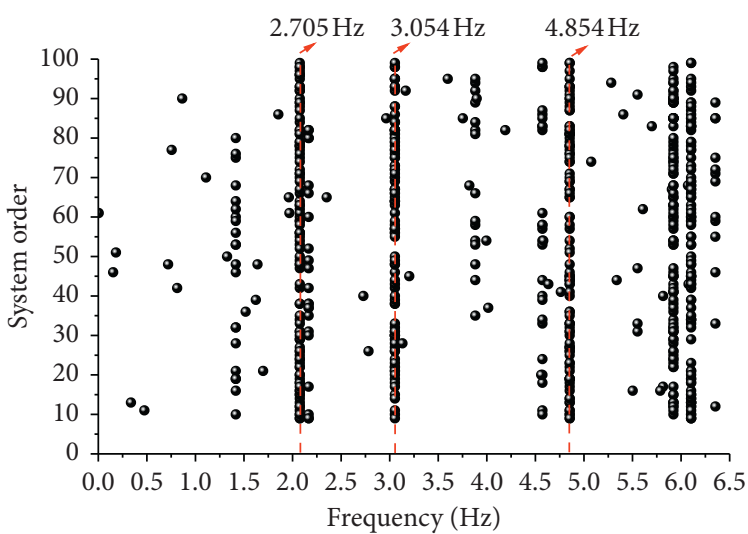

(a)

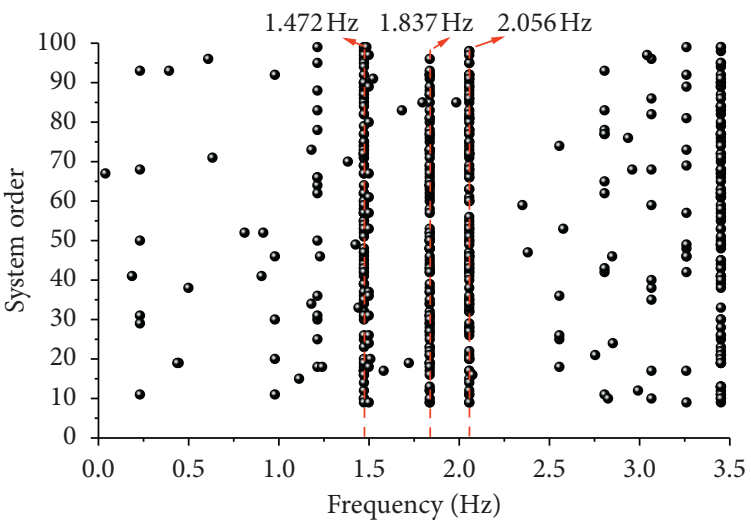

(b)

FIgURE 6: Vibration stability map of stochastic subspace identification. (a) SSI vibration stability diagram of climbing formwork under construction condition. (b) SSI vibration stability diagram of climbing formwork under climbing condition.

TABLE 6: Natural frequency and mode shape of the climbing formwork model.

\begin{tabular}{|c|c|c|c|}
\hline $\begin{array}{l}\text { Finite element } \\
\text { model }\end{array}$ & Mode & $\begin{array}{l}\text { Natural frequency } \\
\qquad(\mathrm{Hz})\end{array}$ & Mode shape \\
\hline \multirow{5}{*}{$\mathrm{COC}$} & 1 & 0.183 & The $X$ direction translation of climbing formwork and core tube \\
\hline & 2 & 0.184 & The $Y$ direction translation of climbing formwork and core tube \\
\hline & 3 & 0.320 & The torsion of climbing formwork and core tube \\
\hline & 4 & 1.973 & The torsion and the bending moment of the upper frame of climbing formwork \\
\hline & 5 & 2.803 & The bending moment of the lower frame of climbing formwork \\
\hline \multirow{5}{*}{ CLC } & 1 & 0.184 & The $X$ direction translation of climbing formwork and core tube \\
\hline & 2 & 0.185 & The $Y$ direction translation of climbing formwork and core tube \\
\hline & 3 & 0.322 & The torsion of climbing formwork and core tube \\
\hline & 4 & 1.021 & $\begin{array}{c}\text { The torsion of the upper frame and the } Y \text { direction translation of climbing formwork } \\
\text { and core tube }\end{array}$ \\
\hline & 5 & 1.431 & The bending moment of the frame and guide rail of climbing formwork \\
\hline \multirow{5}{*}{$\mathrm{CO}$} & 1 & 1.999 & The bending moment of the upper frame of climbing formwork \\
\hline & 2 & 2.890 & The bending moment of the lower frame of climbing formwork \\
\hline & 3 & 4.827 & The torsion of climbing formwork \\
\hline & 4 & 5.928 & The bending moment of the lower frame and peripheral keel of climbing formwork \\
\hline & 5 & 6.095 & The torsion and the bending moment of the upper frame of climbing formwork \\
\hline \multirow{5}{*}{ CL } & 1 & 1.424 & \multirow{5}{*}{$\begin{array}{l}\text { The torsion and the bending moment of the upper frame of climbing formwork } \\
\text { The bending moment of frame and guide rail of climbing formwork } \\
\text { The torsion and the bending moment of frame and guide rail of climbing formwork } \\
\text { The bending moment of the lower frame and guide rail of climbing formwork } \\
\text { The torsion of the upper frame and the bending moment of the lower frame of } \\
\text { climbing formwork }\end{array}$} \\
\hline & 2 & 1.801 & \\
\hline & 3 & 2.004 & \\
\hline & 4 & 3.468 & \\
\hline & 5 & 3.491 & \\
\hline
\end{tabular}

TABLE 7: The first three natural frequencies of the core tube.

\begin{tabular}{lcccc}
\hline \multirow{2}{*}{ Mode of vibration } & \multicolumn{2}{c}{ Natural frequency $(\mathrm{Hz})$} & \multicolumn{2}{c}{ Mode shape } \\
& 0.181 & 0.182 & The $X$ direction translation & The $X$ direction translation \\
& & 0.182 & The $Y$ direction translation & The $Y$ direction translation \\
2 & 0.315 & 0.315 & The torsion of core tube & The torsion of core tube \\
3 & &
\end{tabular}




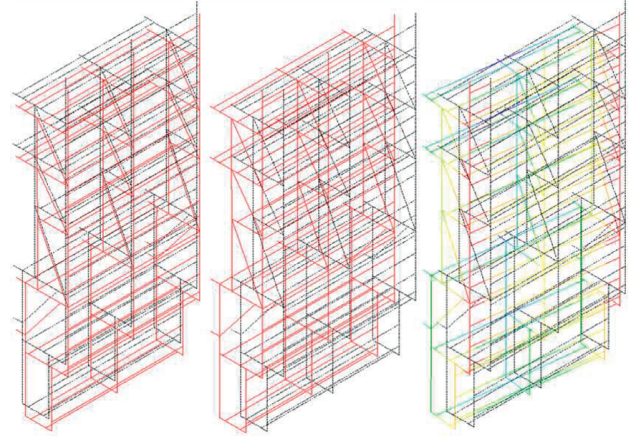

(a)
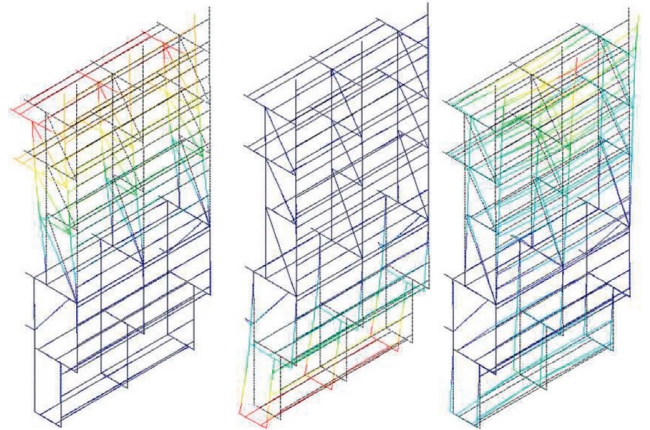

(c)

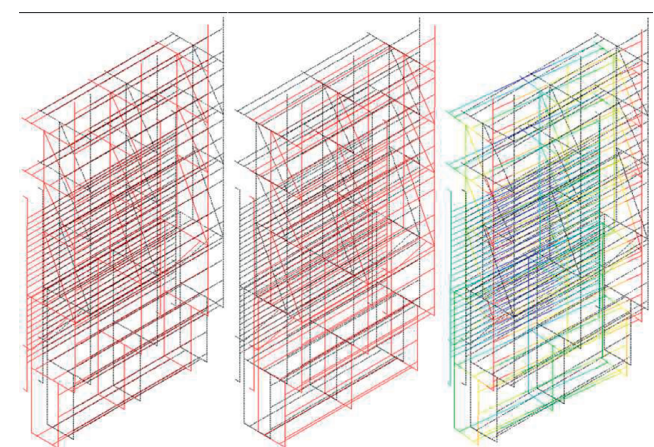

(b)

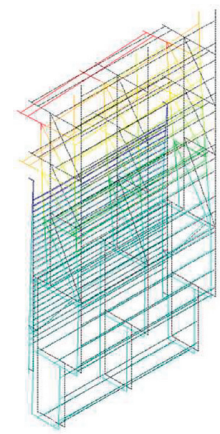

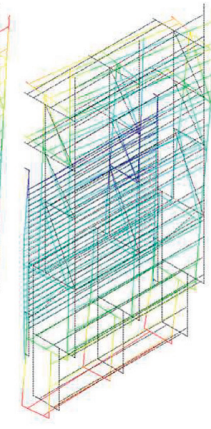

(d)

${ }^{*}$ The black line model stands for the original model, and the color line model stands for the mode shape.

0 Max

(e)

Figure 7: The mode shape diagrams of the first three modes of the model COC/CLC/CO/CL. (a) Mode shape diagrams of COC. (b) Mode shape diagrams of CLC. (c) Mode shape diagrams of CO. (d) Mode shape diagrams of CL. (e) Color bar of the difference between the mode shape and the original model.

subjected to the different earthquakes, and the climbing formwork follows the vibration of the core tube and produces the large displacement. It is concluded that the displacement of the climbing formwork under the construction condition is greatly affected by the core tube.

(3) Under the construction condition, the maximum von Mises stress of the climbing formwork exceeds $224 \mathrm{MPa}$ and occurs at the joint of the outer pole of main platform and the tripod, indicating that the outer pole of main platform is close to yielding under various construction conditions. It is recommended to strengthen and stiffen the outer pole of the main platform and tripod.

Since the load on the platform beam of the upper platform is complicated and the displacement is obvious, the center node of the long beam of the upper platform (the maximum displacement node in Figure 10; node 704 in the Ansys model CO) is the research object. The displacement-time curves of the node are shown in Figure 11. When considering the influence of the core tube, the center node of the long beam of upper platform (node 704 in COC model) and connection point of the core tube model and the climbing formwork (node 3502 in $\mathrm{CO}$ model) are taken as the research object.

The displacement-time history curves of the two nodes (nodes 704 and 3502 in COC model) are shown in Figure 12.
At the same time, the displacement difference-time curves of the two nodes are shown in Figure 13.

The following can be seen from Figures 11 to 13 .

(1) It can be seen from Figure 11 that, under the climbing condition, the $X$ direction displacement of the climbing formwork model CO fluctuates up and down at $-5 \mathrm{~mm}$. The $Y$ direction displacement fluctuates up and down at $0 \mathrm{~mm}$. The $Z$ direction displacement fluctuates slightly up and down at $-22 \mathrm{~mm}$. The vibration amplitude in the $Y$ direction is obviously larger than that in the $X$ direction and $Z$ direction, but the peak value of $Y$ direction displacement is smaller than the $X$ direction and $Z$ direction. The reason is that, under the construction condition, the outermost beam of the upper platform is subjected to gravity load and construction load, which cause the large static displacement in the $X$ direction and $Z$ direction. From Figure 11, it can be seen that, under the three dimensional earthquakes, the $Y$ direction vibration of the climbing formwork is the most severe, indicating that the climbing formwork is most sensitive to the $Y$ direction earthquake.

(2) As can be seen from Figure 12, under the climbing condition, the $Y$ direction and $X$ direction displacements of the climbing formwork model COC are large, and both fluctuate up and down at $0 \mathrm{~mm}$. Under the different earthquakes, the displacement-time curves of 
Cape Mendocino

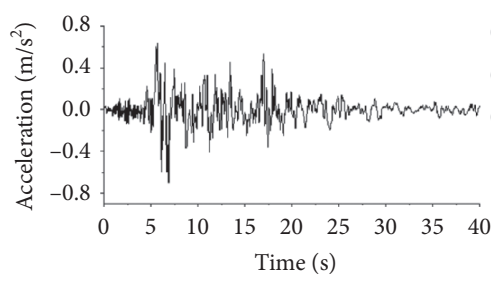

$x$-direction

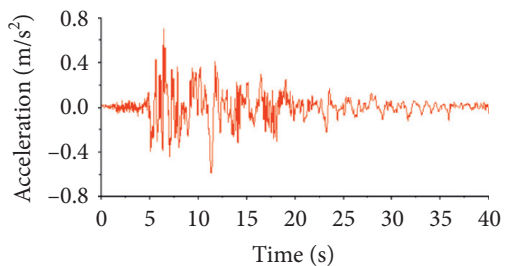

$y$-direction

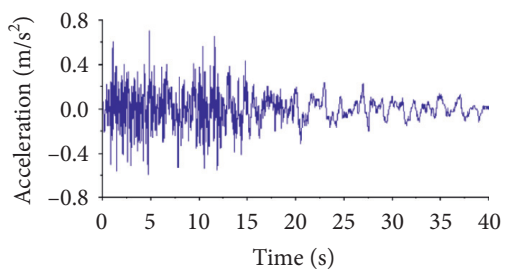

Turkey Duzce

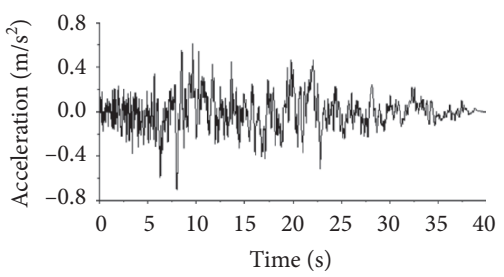

$x$-direction

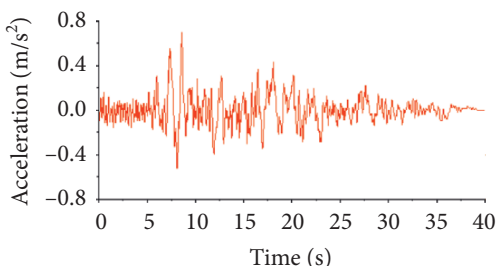

$y$-direction

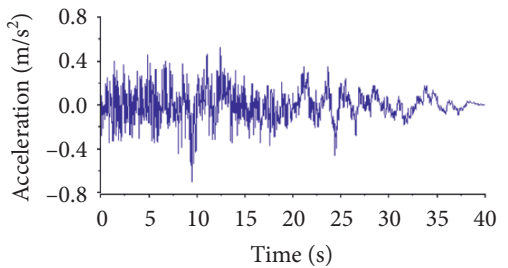

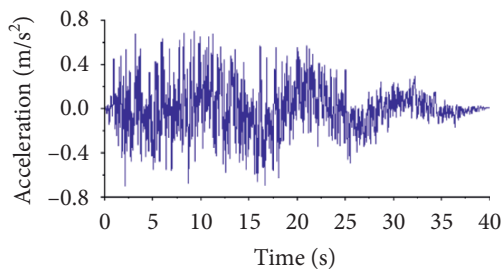

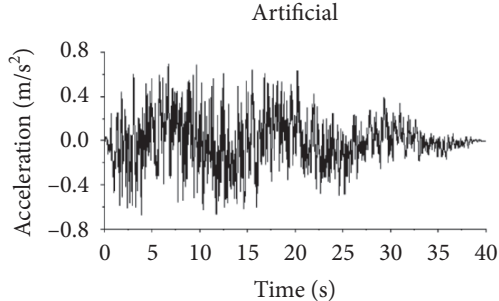

$x$-direction

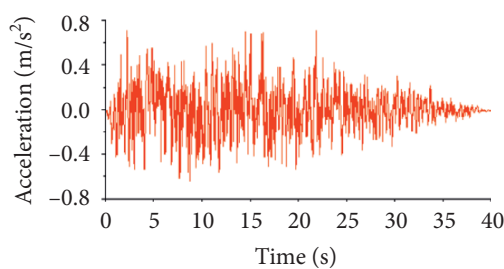

$y$-direction

$z$-direction

$z$-direction

Figure 8: Acceleration time history of Cape Mendocino and Turkey Duzce and artificial seismic record.

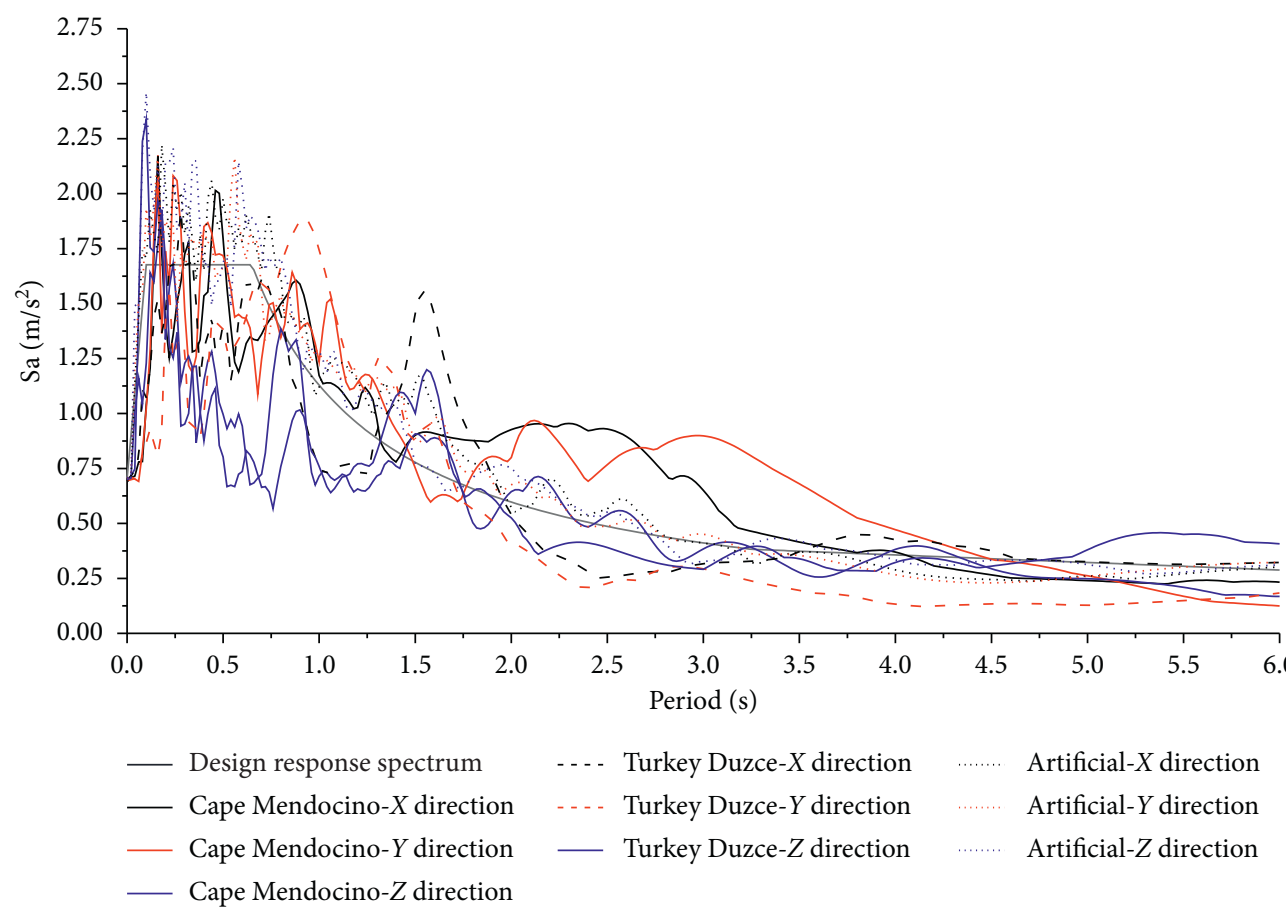

Figure 9: Response spectrum curves of seismic records selected and design response spectrum curve. 


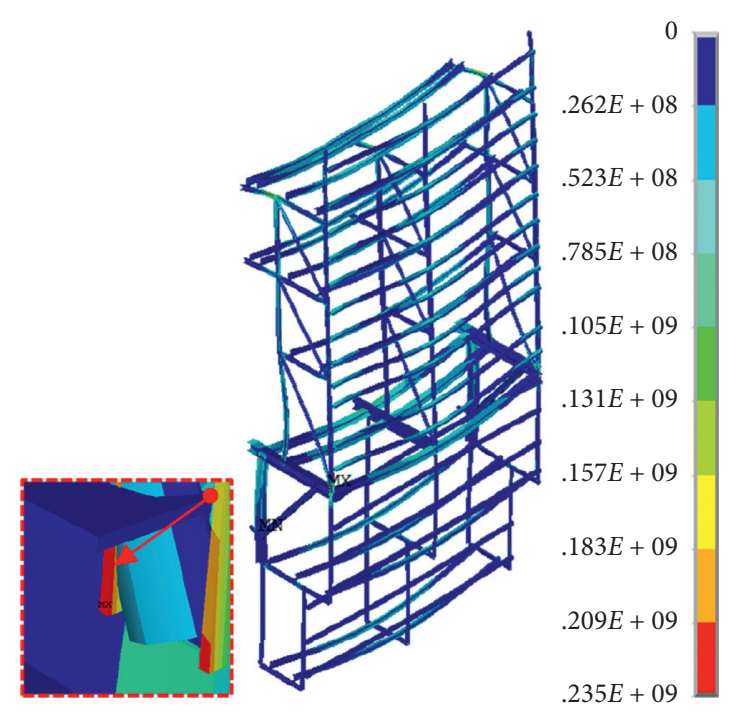

(a)
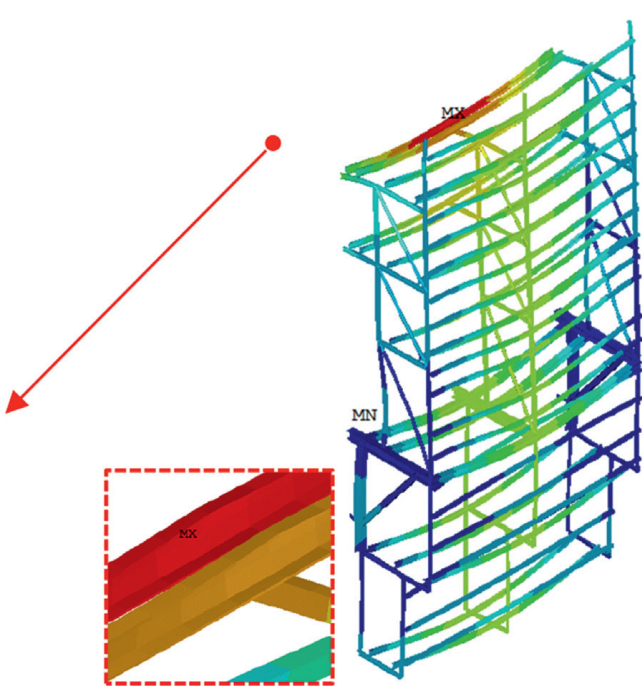

0
.002725
.00545
.008175
.0109
.013625
.01635
.019075
.0218
.024526

(b)

FIGURE 10: Peak nephogram of climbing formwork under the working condition CO-CM. (a) Peak von Mises stress nephogram (N/m²); (b) peak displacement nephogram $(\mathrm{m})$. MX stands for maximum von Mises stress point and maximum displacement point. MN stands for minimum von Mises stress point and minimum displacement point.

TABLE 8: Structure peak response of climbing formwork under the construction condition.

\begin{tabular}{|c|c|c|c|c|}
\hline $\begin{array}{l}\text { Working } \\
\text { condition }\end{array}$ & $\begin{array}{l}\text { Maximum von Mises } \\
\text { stress }\left(\mathrm{N} / \mathrm{mm}^{2}\right)\end{array}$ & Position of maximum stress & $\begin{array}{c}\text { Maximum } \\
\text { displacement }(\mathrm{mm})\end{array}$ & $\begin{array}{c}\text { Position of maximum } \\
\text { displacement }\end{array}$ \\
\hline $\mathrm{COC}-\mathrm{CM}$ & 224 & $\begin{array}{c}\text { Joint of the outer pole of main } \\
\text { platform and the tripod }\end{array}$ & 175 & $\begin{array}{c}\text { Center of the long beam of } \\
\text { upper platform }\end{array}$ \\
\hline COC-TD & 232 & $\begin{array}{c}\text { Joint of the outer pole of main } \\
\text { platform and the tripod }\end{array}$ & 244 & $\begin{array}{c}\text { Center of the long beam of } \\
\text { upper platform }\end{array}$ \\
\hline COC-AR & 227 & $\begin{array}{l}\text { Joint of the outer pole of main } \\
\text { platform and the tripod }\end{array}$ & 223 & $\begin{array}{c}\text { Center of the long beam of } \\
\text { upper platform }\end{array}$ \\
\hline $\mathrm{CO}-\mathrm{CM}$ & 235 & $\begin{array}{c}\text { Joint of the outer pole of main } \\
\text { platform and the tripod }\end{array}$ & 24.5 & $\begin{array}{c}\text { Center of the long beam of } \\
\text { upper platform }\end{array}$ \\
\hline CO-TD & 234 & $\begin{array}{c}\text { Joint of the outer pole of main } \\
\text { platform and the tripod }\end{array}$ & 24.4 & $\begin{array}{c}\text { Center of the long beam of } \\
\text { upper platform }\end{array}$ \\
\hline CO-AR & 225 & $\begin{array}{c}\text { Joint of the outer pole of main } \\
\text { platform and the tripod }\end{array}$ & 24.4 & $\begin{array}{c}\text { Center of the long beam of } \\
\text { upper platform }\end{array}$ \\
\hline
\end{tabular}

the climbing formwork have obvious differences. The $Z$ direction displacement of the climbing formwork changes substantially with time at $-23 \mathrm{~mm}$. The displacement-time curves of the climbing formwork node and core tube node substantially coincide in the $X$ direction and $Y$ direction. At the same time, as can be seen from Figure 13, the displacement differences of that in the $X$ direction and the $Y$ direction are within $10 \mathrm{~mm}$. The $Z$ direction displacement difference is about $-23 \mathrm{~mm}$, which is mainly caused by the construction load of the climbing formwork in the $Z$ direction. The aforementioned shows that when considering the influence of the core tube, the vibration displacement of the climbing formwork is mainly contributed by the displacement of the core tube.
(3) Under the construction condition, when the climbing formwork is subjected to gravity load, wind load, construction load, and three-dimensional earthquakes, the displacement of the climbing formwork in the $Z$ direction is about $-23 \mathrm{~mm}$, and the fluctuations are small. It can be concluded that the vertical displacement of the climbing formwork is primarily defined by the gravity load and construction load, and the climbing formwork is insensitive to the $Z$ direction earthquake. From the comparison of Figures 11 and 12, the vibration frequency of the climbing formwork model COC under the earthquakes is small, and the vibration amplitudes in the $X$ direction and the $Y$ direction are not much different. The vibration frequency of the 


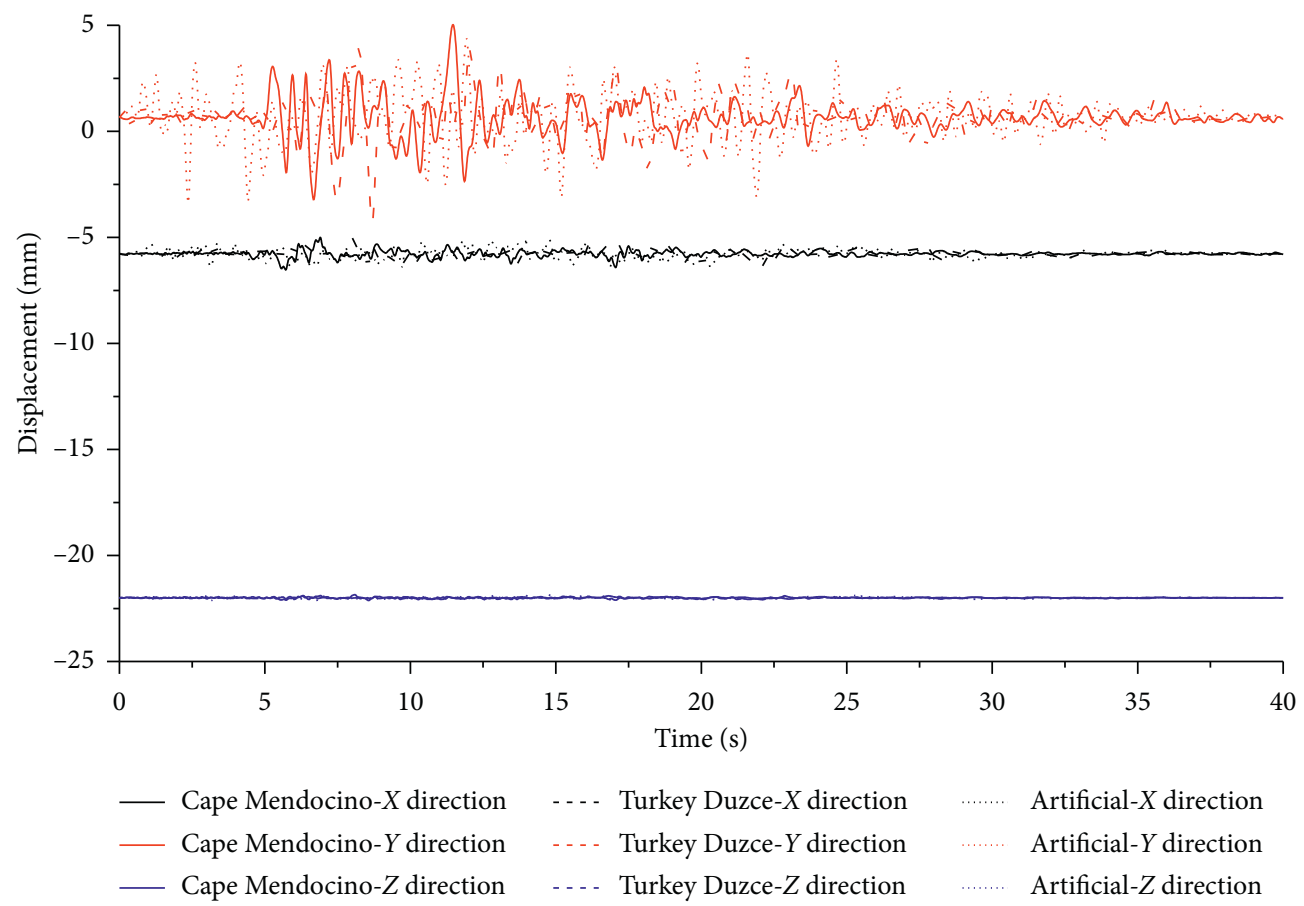

FIGURE 11: Displacement-time curves of climbing formwork without core tube under the construction condition.

climbing formwork model $\mathrm{CO}$ is large and the vibration amplitude in the $Y$ direction is larger than that in the $X$ direction. It can be seen that, under the earthquake, the response of the core tube reduces the vibration frequency of the climbing formwork under the construction condition and reduces the sensitivity of the climbing formwork to the earthquake. It shows that, under the earthquake, the vibration frequency and vibration amplitude of the climbing formwork are greatly affected by the core tube.

5.3. Seismic Response of Climbing Formwork under the Climbing Condition. Maximum von Mises stress and maximum displacement of the climbing formwork under the climbing condition are analyzed for evaluating the seismic response. Table 9 shows the structural peak response of the climbing formwork. Regardless of the core tube, the displacement-time curves of node 704 (CL model) are shown in Figure 14. Considering the influence of the core tube under the climbing condition, the displacement-time curves and the displacement difference-time curves of nodes 704 and 3502 (CLC model) are as shown in Figures 15 and 16.

The following can be seen from Table 9 .

(1) Under the climbing condition, the maximum displacement position of the climbing formwork is at the top of the outer pole of upper platform, and it is recommended to strengthen the constraint. The maximum von Mises stress position of the climbing formwork is the joint of the beam of tripod and the guide rail. The maximum von Mises stress did not exceed the yield strength of $235 \mathrm{MPa}$, indicating that the components did not yield.

(2) Under the climbing condition, regardless of the influence of the core tube (CL model), the maximum displacement position and the maximum von Mises stress position of CL model are the same as CLC model. The maximum von Mises stress value of CL model is similar to CLC model, but the maximum displacement value of CL model is much smaller than CLC model. It shows that, under the different earthquakes, the displacement of the climbing formwork under the climbing condition is greatly affected by the core tube.

(3) It can be seen from the comparison between Tables 8 and 9 that the seismic response of the climbing formwork is significantly different under the construction condition and the climbing condition. The maximum von Mises stress of the climbing formwork under the construction condition is larger than that under the climbing condition. When the influence of the core tube is not considered, the maximum displacement of the climbing formwork under the climbing condition is significantly larger than that under the construction condition. The reason is that, under the climbing condition, the guide rail is deformed in the $X$ direction, and the upper frame of the climbing formwork is not connected with the guide rail, which causes a large $X$ direction displacement of the upper frame.

The following can be seen from Figures 14 to 16 .

(1) It can be seen from Figure 14 that, under the climbing condition, the $X$ direction displacement of 

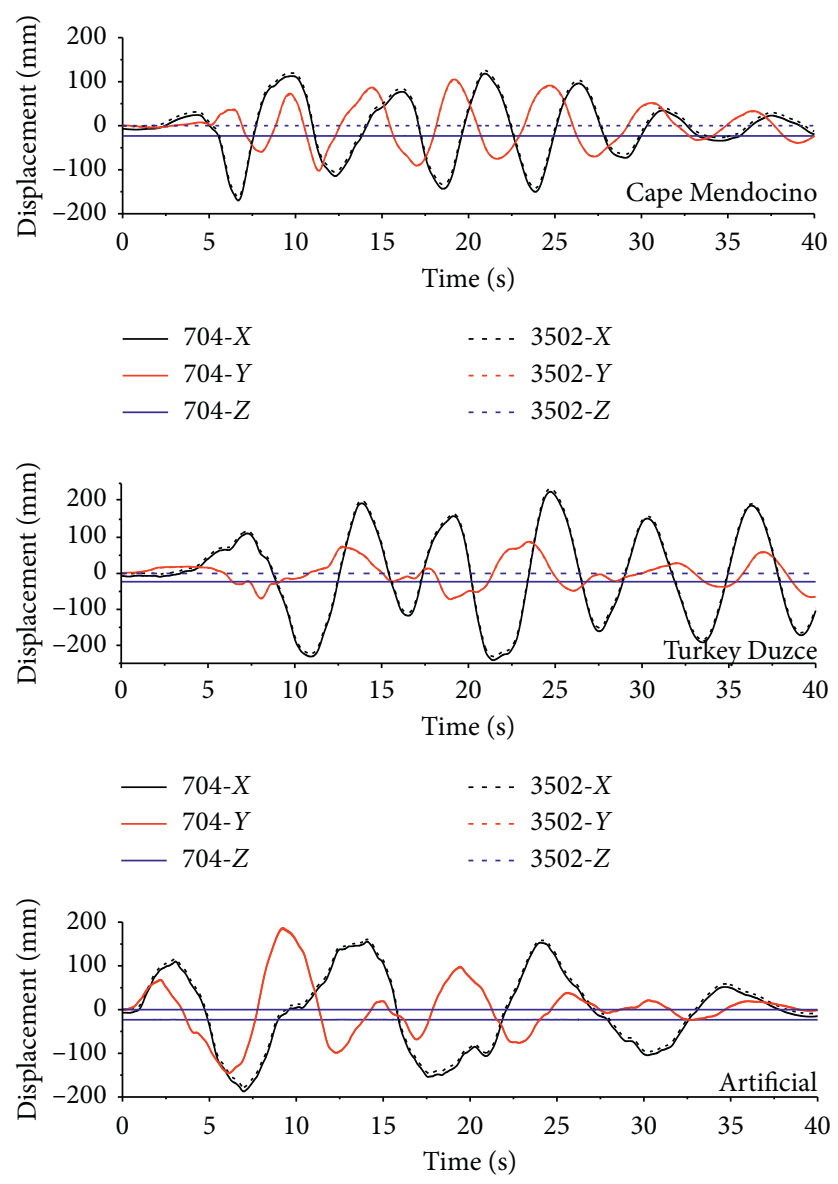

$\begin{array}{lll}-704-X & \ldots & 3502-X \\ -704-Y & \ldots . & 3502-Y \\ -704-Z & \ldots . & 3502-Z\end{array}$

FIGURE 12: Displacement-time curves of climbing formwork with core tube under the construction condition.

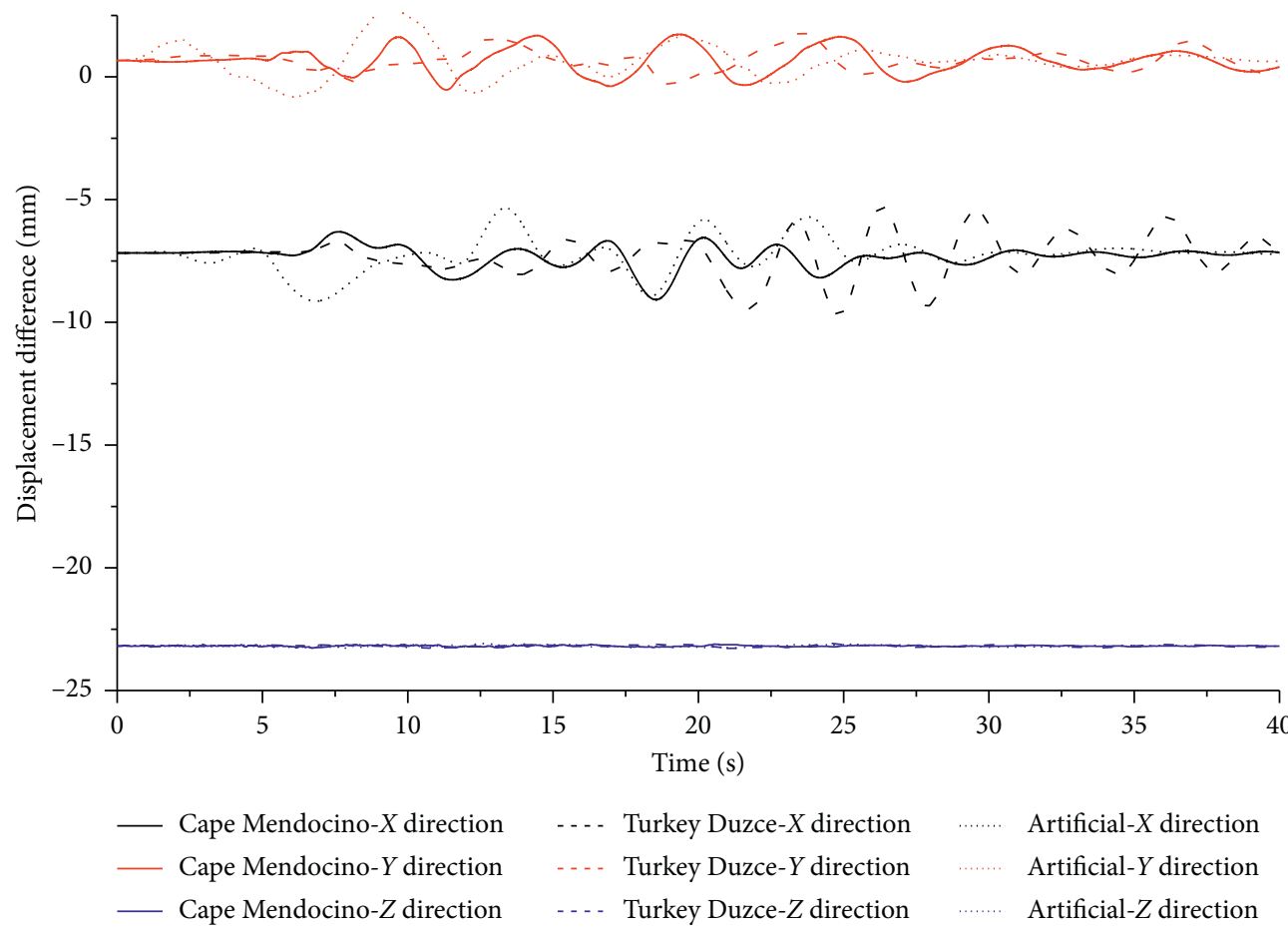

FIGURE 13: Displacement difference-time curves of climbing formwork and core tube under the construction condition. 
TABLE 9: Structure peak response of climbing formwork under the climbing condition.

\begin{tabular}{|c|c|c|c|c|}
\hline $\begin{array}{l}\text { Working } \\
\text { condition }\end{array}$ & $\begin{array}{l}\text { Maximum von Mises stress } \\
\left(\mathrm{N} / \mathrm{mm}^{2}\right)\end{array}$ & Position of maximum stress & $\begin{array}{l}\text { Maximum displacement } \\
(\mathrm{mm})\end{array}$ & $\begin{array}{c}\text { Position of maximum } \\
\text { displacement }\end{array}$ \\
\hline CLC-CM & 170 & $\begin{array}{c}\text { Joint of the beam of tripod and } \\
\text { the guide rail }\end{array}$ & 223 & $\begin{array}{c}\text { Top of the outer pole of upper } \\
\text { platform }\end{array}$ \\
\hline CLC-TD & 173 & $\begin{array}{c}\text { Joint of the beam of tripod and } \\
\text { the guide rail }\end{array}$ & 340 & $\begin{array}{c}\text { Top of the outer pole of upper } \\
\text { platform }\end{array}$ \\
\hline CLC-AR & 172 & $\begin{array}{c}\text { Joint of the beam of tripod and } \\
\text { the guide rail }\end{array}$ & 243 & $\begin{array}{c}\text { Top of the outer pole of upper } \\
\text { platform }\end{array}$ \\
\hline CL-CM & 171 & $\begin{array}{c}\text { Joint of the beam of tripod and } \\
\text { the guide rail }\end{array}$ & 71.2 & $\begin{array}{c}\text { Top of the outer pole of upper } \\
\text { platform }\end{array}$ \\
\hline CL-TD & 172 & $\begin{array}{c}\text { Joint of the beam of tripod and } \\
\text { the guide rail }\end{array}$ & 70.0 & $\begin{array}{c}\text { Top of the outer pole of upper } \\
\text { platform }\end{array}$ \\
\hline CL-AR & 165 & $\begin{array}{l}\text { Joint of the beam of tripod and } \\
\text { the guide rail }\end{array}$ & 67.6 & $\begin{array}{c}\text { Top of the outer pole of upper } \\
\text { platform }\end{array}$ \\
\hline
\end{tabular}

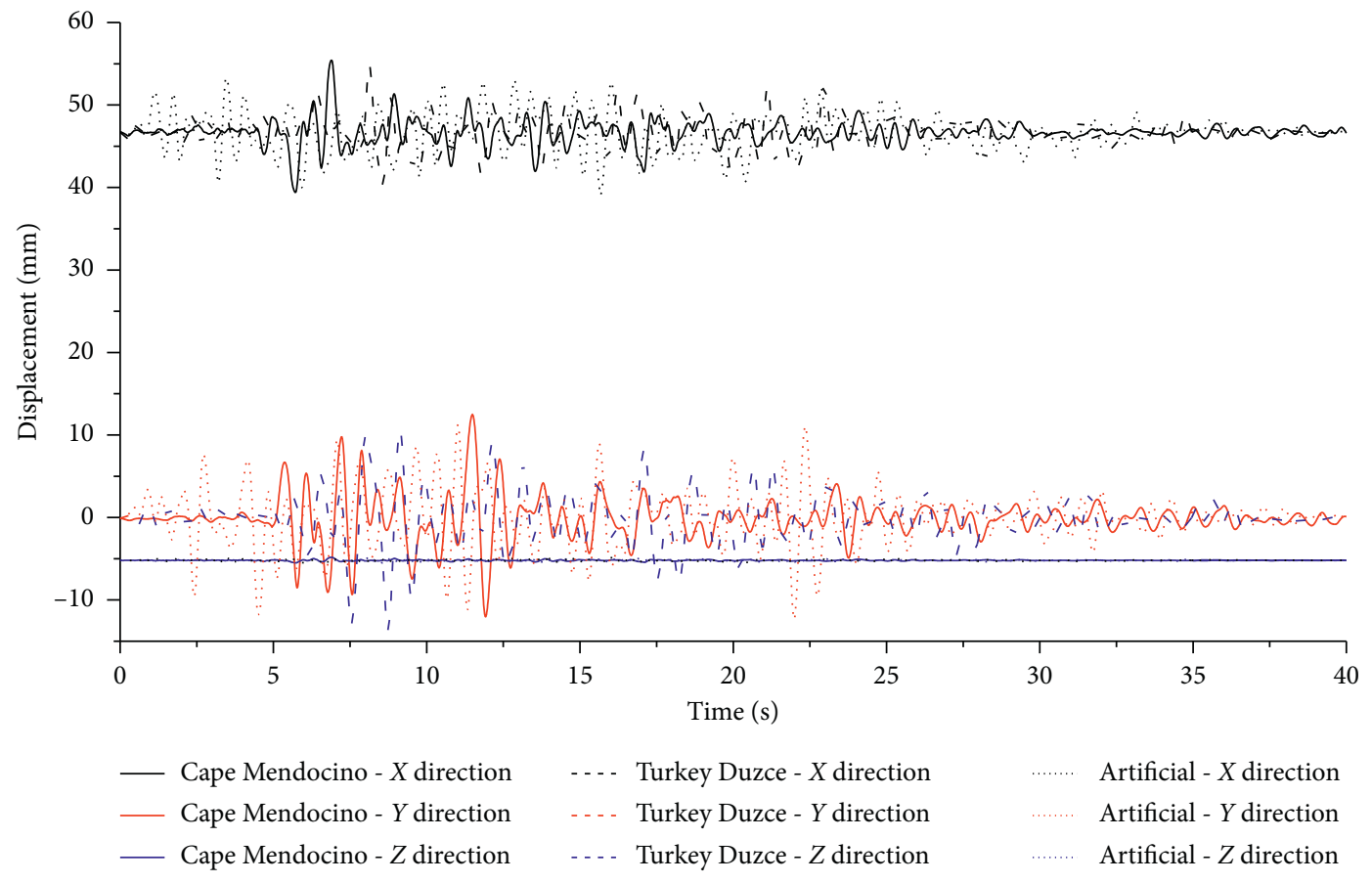

Figure 14: Displacement-time curves of climbing formwork without core tube under the climbing condition.

the climbing formwork model CL fluctuates up and down at $46 \mathrm{~mm}$. The $Y$ direction displacement fluctuates up and down at $0 \mathrm{~mm}$, and the $Z$ direction displacement fluctuates slightly up and down at $5 \mathrm{~mm}$. The vibration amplitude in the $Y$ direction is slightly larger than that in the $X$ direction. The $Y$ direction vibration amplitude is about $20 \mathrm{~mm}$, and the $X$ direction displacement vibration amplitude is about $10 \mathrm{~mm}$. Comparing Figure 11, under the construction condition, the vibration amplitude in $Y$ direction is about $10 \mathrm{~mm}$, and the vibration amplitude in the $X$ direction is about $3 \mathrm{~mm}$, which is smaller than that under the climbing condition. It shows that, under the climbing condition, the climbing formwork is more sensitive to the $Y$ direction and $X$ direction earthquakes.
(2) It can be seen from Figure 15 that, under the climbing condition, the $X$ direction and the $Y$ direction displacement-time curves of the climbing formwork model CLC under different earthquakes are obviously different, and the $Z$ direction displacement-time curve remains basically unchanged under different earthquakes. The displacement-time curves of climbing formwork node and the core tube node substantially coincide in the $Y$ direction and $Z$ direction. The climbing formwork node has the same displacement trend as the core tube node in the $X$ direction but has a large displacement difference. It can be seen from Figure 16 that the displacement differences of that in the $Y$ direction and $Z$ direction are within $5 \mathrm{~mm}$, and the $X$ direction displacement difference is about $60 \mathrm{~mm}$. The main reason is that 

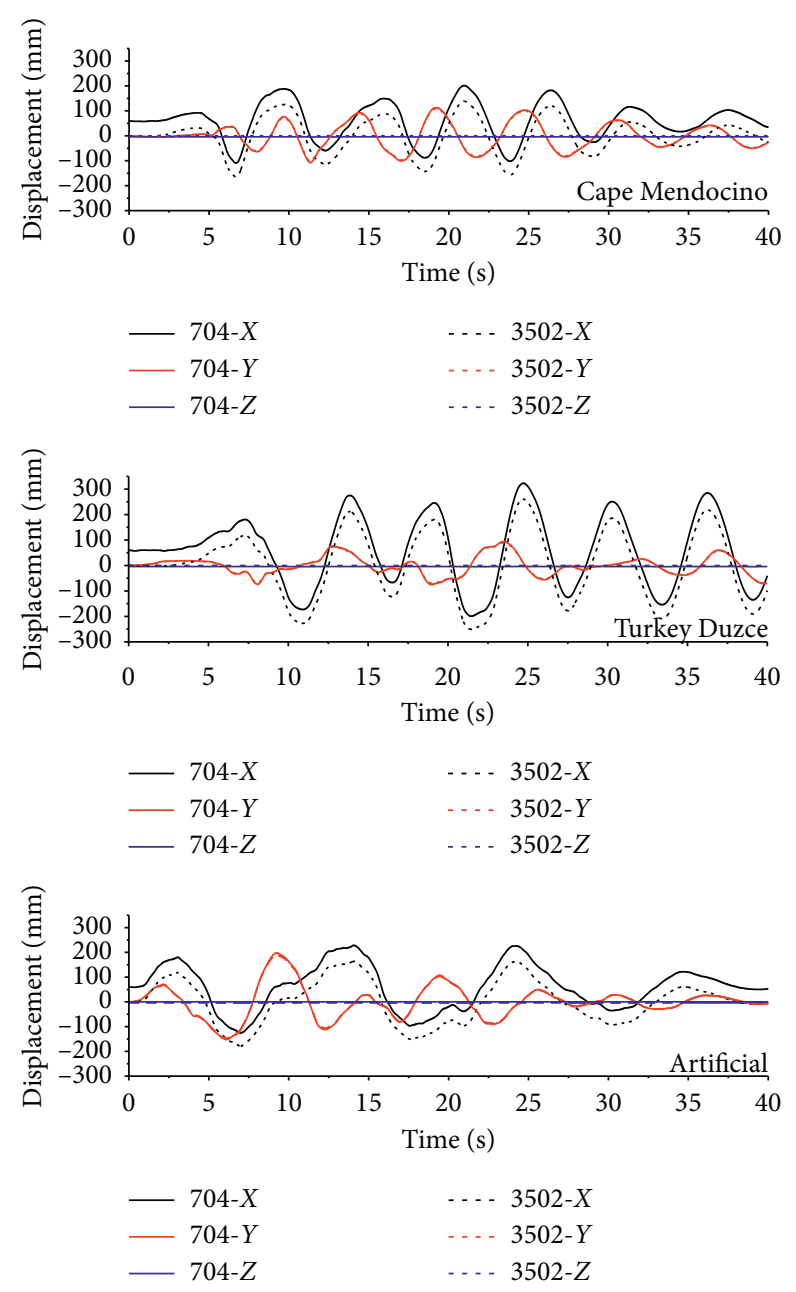

FIGURE 15: Displacement-time curves of climbing formwork with core tube under the climbing condition.

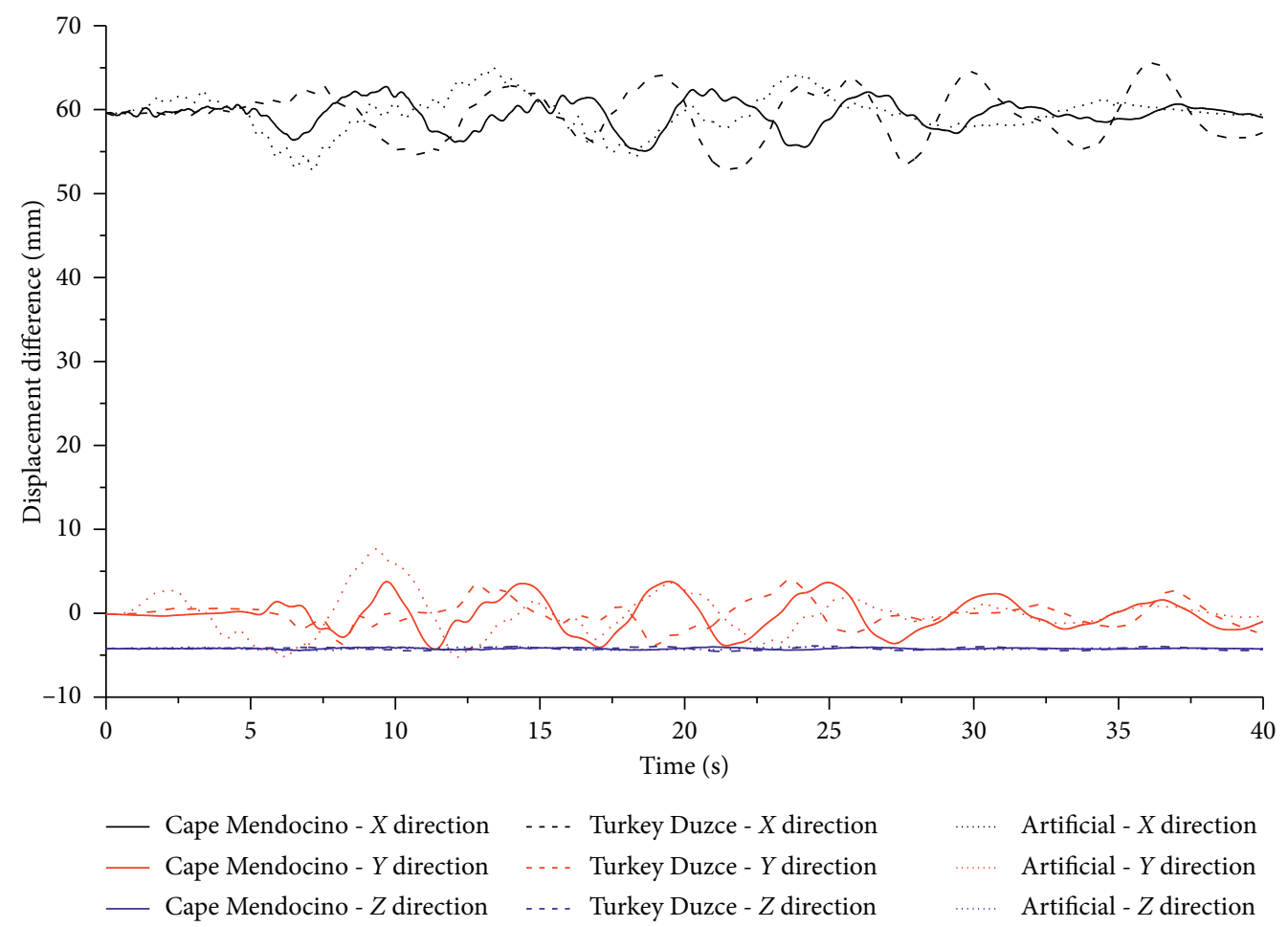

FIGURE 16: Displacement difference-time curves of climbing formwork and core tube under the climbing condition. 
the climbing formwork frame is attached to the guide rail under the climbing condition, and there is no connection between the upper parts. When the climbing formwork is subjected to gravity load, wind load, and earthquake together, the guide rail will produce a large $X$ direction bending deformation, and the upper part of the climbing formwork body will deviate from the guide rail, resulting in a large $X$ direction displacement difference.

(3) It can be seen from the comparison between Figures 14 and 16 that the vibration frequency of the climbing formwork model CLC is small, and the vibration amplitudes in the $X$ direction and the $Y$ direction of the climbing formwork are not much different. The vibration frequency of the climbing formwork model CL is large, and the $Y$ direction vibration amplitude is larger than the $X$ direction. It can be seen that, subjected to the earthquake, the response of the core tube reduces the vibration frequency of the climbing formwork under the climbing condition and the sensitivity of the climbing formwork to the earthquake. By comprehensively comparing all displacement-time curves, the $Y$ direction vibration amplitude of the climbing formwork is the largest, the $X$ direction vibration amplitude is slightly smaller, and the $Z$ direction vibration amplitude is extremely small. It shows that the climbing formwork is the most sensitive to the $Y$ direction earthquake, and the sensitivity to the $X$ direction earthquake is slightly smaller, and it is insensitive to the $Z$ direction earthquake.

\section{Conclusion}

Based on the climbing formwork used in actual engineering, this study established a finite element model of climbing formwork. By studying and analyzing the dynamic characteristics and the seismic response of the climbing formwork under different working conditions, the following can be concluded.

(1) The natural frequencies of first three modes of the simplified core tube model are basically equal to that of the accurate PKPM model. The natural frequency of the climbing formwork model is basically equal to that of the actual climbing formwork. The established finite element model is highly accurate.

(2) Under the construction condition, the maximum displacement position of the climbing formwork is at the center of long beam of the upper platform. For the climbing condition, the maximum displacement position of the climbing formwork is at the top of the outer pole of upper platform. It is recommended to strengthen the connection between the upper platform and guide rail.

(3) Under the construction conditions, the maximum von Mises stress position is the joint of the outer pole of main platform and the tripod, which is close to or reaches the yield strength. Under the climbing condition, the maximum von Mises stress position is the joint of the beam of tripod and the guide rail, but the components do not yield. The climbing formwork is partially damaged under the simulated earthquake. Some components have reached the yield state, and the plastic deformation failure has begun. It is recommended to strengthen and stiffen the outer pole of the main platform and tripod.

(4) Under the earthquake, the response of the core tube reduces the vibration frequency of the climbing formwork and the sensitivity of the climbing formwork to the earthquake. During the earthquake, the natural frequency and vibration amplitude of the climbing formwork are greatly affected by the core tube.

(5) Subjected to the earthquake, the climbing formwork is the most sensitive to the $Y$ direction earthquake, the sensitivity to the $X$ direction earthquake is slightly smaller, and it is insensitive to the $Z$ direction earthquake. Under the climbing condition, especially, the climbing formwork is more sensitive to the $Y$ direction and $X$ direction earthquakes.

\section{Data Availability}

The data used to support the findings of this study are available from the corresponding author upon request.

\section{Conflicts of Interest}

The authors declare that they have no conflicts of interest.

\section{Acknowledgments}

This work was financially supported by the Fundamental Research Funds for the Central Universities (2020CDJQYA067) and National Key R\&D Program of the Ministry of Science and Technology (2019YFD1101005-4).

\section{References}

[1] M. R. Kannan and M. H. Santhi, "Constructability assessment of climbing formwork systems using building information modeling," in Proceedings of the International Conference on Design and Manufacturing, vol. 64, pp. 1129-1138, Chennai, India, November 2013.

[2] J. Gong, X. A. Wang, and Y. L. Huang, "The research progress on structure design calculation method of integral climbing steel platform formwork equipment," in Proceedings of the 14th International Symposium on Structural Engineering, pp. 1327-1337, Beijing, China, March 2016.

[3] Y. P. Zou, X. H. Liu, and Z. Q. Dai, "The design and application of the alternate climbing formwork to the III-stage RCC cofferdam of the Three Gorges Project," in Proceedings of the 4th International Symposium on Roller Compacted Concrete Dams, pp. 541-544, Madrid, Spain, November 2003.

[4] J. P. Li, J. Ruan, P. Tan et al., "Simulation analysis and structure optimization of steel structure climbing formwork with material properties used in the large angle leaning bridge tower," in Proceedings of the 2nd International Conference on 
Applied Mechanics and Manufacturing System, vol. 540, pp. 201-204, Zhengzhou, China, October 2014.

[5] Y. Shin, T. Kim, H. Cho et al., "A formwork method selection model based on boosted decision trees in tall building construction," Automation in Construction, vol. 23, pp. 47-54, 2013.

[6] E. M. Golafshani and S. Talatahari, "Predicting the climbing rate of slip formwork systems using linear biogeographybased programming," Applied Soft Computing, vol. 70, pp. 263-278, 2018.

[7] K. Ju, K. Min, L. Taehoon et al., "Automated layout planning of climbing formwork system using genetic algorithm," in Proceedings of the 33rd International Symposium on Automation and Robotics in Construction, pp. 770-777, Alabama, USA, July 2016.

[8] China Earthquake Administration, Overview of the Earthquake and Disaster Situation in 2018, China Earthquake Administration, Chinahttps://www.cea.gov.cn/cea/index/ index.html.

[9] X. Z. Lu, M. K. Li, H. Guan et al., "A comparative case study on seismic design of tall RC frame-core-tube structures in China and USA," Structural Design of Tall and Special Buildings, vol. 24, no. 9, pp. 687-702, 2015.

[10] L. Zeng, Y. F. Xiao, Y. G. Chen et al., "Seismic damage evaluation of concrete-encased steel frame-reinforced concrete core tube buildings based on dynamic characteristics," Applied Sciences-Basel, vol. 7, no. 4, p. 314, 2017.

[11] Z. Lu, X. Chen, X. Lu, and Z. Yang, "Shaking table test and numerical simulation of an RC frame-core tube structure for earthquake-induced collapse," Earthquake Engineering \& Structural Dynamics, vol. 45, no. 9, pp. 1537-1556, 2016.

[12] Z. D. Rong, "Discussion on the technology of full hydraulic climbing formwork in super high-rise building construction," Chinese Architectural Science, vol. 19, pp. 248-249, 2014.

[13] X. Y. Liu, Y. M. Hu, D. Y. Che et al., "Safety control of hydraulic self-climbing formwork in south tower construction of Taizhou Bridge," in Proceedings of the 8th International Symposium on Safety Science and Technology, vol. 45, pp. 248-252, Nanjing, China, October 2012.

[14] S. C. Hu and J. Li, "Analysis of dynamic characteristics of climbing formwork under wind loads," in Proceedings of the 2018 International Symposium on Architecture Research Frontiers and Ecological Environment, Wuhan, China, December 2018.

[15] L. G. Shi, C. M. Xiang, and L. Z. Yan, "Numerical analysis of seismic performance of hydraulic climbing formwork in kunming xishan Wanda Plaza," Construction Technology, vol. 46, no. 21, pp. 98-101, 2017.

[16] G. Yao, C. C. Xu, C. Xu et al., "Working mechanism of a highperformance tower crane attached to wall joints," Journal of Engineering Science and Technology Review, vol. 11, no. 1, pp. 19-27, 2018.

[17] G. Yao, H. Li, Y. Yang et al., "Seismic responses and dynamic characteristics of boom tower crane basing on measured strong earthquake excitation," Journal of Vibroengineering, vol. 21, pp. 154-169, 2019.

[18] Ministry of Housing and Urban-Rural Development of the People's Republic of China, Notice of Investigation and Supervision of Housing and Municipal Engineering Safety Accidents, Ministry of Housing and Urban-Rural Development of the People's Republic of China, China, 2019, http://www. mohurd.gov.cn/.

[19] L. X. Yan, "Vibration characteristics and seismic response analysis of tower grid structure on the top of high-rise buildings," Chinese Railway Construction, vol. 9, pp. 2-4, 2001.

[20] J. B. Wang, H. L. Qian, X. Y. Yang, Y. J. Jiang, and H. J. Wang, "Analysis and optimization of the climbing process of a formclimbing system based on a high-rise project," Sichuan Architecture, vol. 40, no. 5, pp. 44-47, 2020.

[21] JGJ 195-2010. Technical specification for hydraulic climbing formwork engineering, China.

[22] G. Yao, Y. Yang, G. Liao et al., "Mechanical performance study of tower crane braced frame joint with different embedded part parameters," Advances in Materials Science and Engineering, vol. 2019, Article ID 3757259, 14 pages, 2019.

[23] Y. Yang, L. Yang, B. Wu et al., "Safety prediction using vehicle safety evaluation model passing on long-span bridge with fully connected neural network," Advances in Civil Engineering, vol. 2019, Article ID 8130240, 12 pages, 2019.

[24] Y. Yang, Y. B. Yang, and Z. X. Chen, "Seismic damage assessment of RC structures under shaking table tests using the modified direct stiffness calculation method," Engineering Structures, vol. 131, pp. 574-586, 2017.

[25] Y. Yang, Q. Cheng, Y. H. Zhu et al., "Feasibility study of tractor-test vehicle technique for practical structural condition assessment of beam-like bridge deck," Remote Sensing, vol. 12, Article ID 114, 2020.

[26] GB 50011-2010. "Code for Seismic Design of Buildings, China”. 